Electronic scientific and practical journal INTELLECTUALIZATION OF LOGISTICS AND SUPPLY CHAIN MANAGEMENT

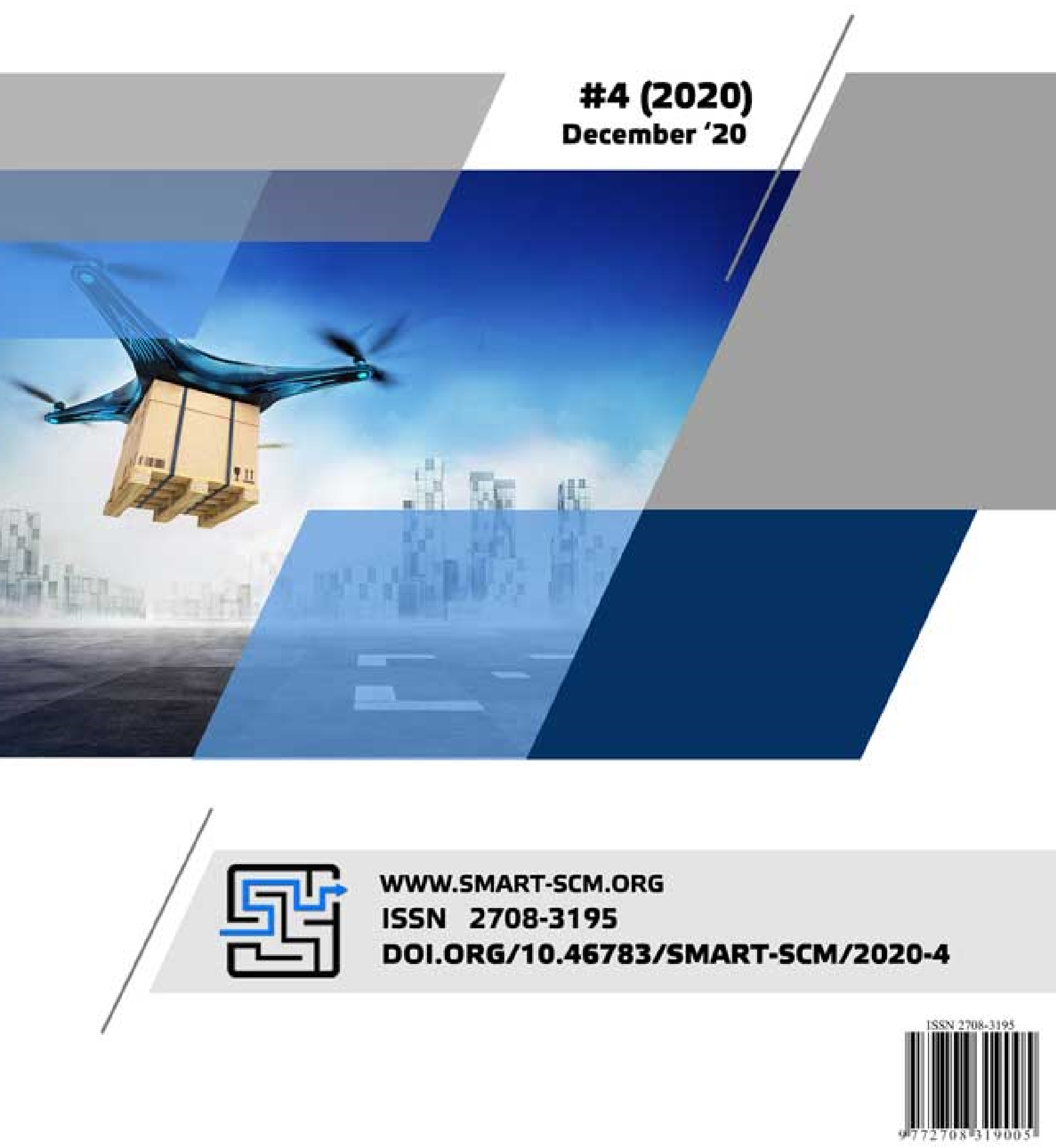




\section{Electronic scientific and practical collection
INTELLECTUALIZATION OF LOGISTICS
AND SUPPLY CHAIN MANAGEMENT}

Electronic scientific and practical publication in economic sciences

ISSN 2708-3195

DOl: https://doi.org/10.46783/smart-scm/2020-4

Released 6 times a year

№ 4 (2020)

December 2020

Kyiv - 2020 
Founder: Viold Limited Liability Company

Editor in Chief:

Deputy editors-in-chief:

Technical editor:

Executive Secretary:
Hryhorak M. Yu. - Doctor of Economics, Ass. Professor.

Koulyk V. A. - PhD (Economics), Professor.

Marchuk V. Ye. - Doctor of Tech. Sci., Ass. Professor.

Harmash O. M. - PhD (Economics), Ass. Professor.

Davidenko V. V. - PhD (Economics), Ass. Professor.

\section{Members of the Editorial Board:}

SWIEKATOWSKI Ryszard - Doctor of Economics, Professor (Poland);

POSTAN M. Ya. - Doctor of Economics, Professor;

TRUSHKINA N. V. - PhD (Economics), Corresponding Member of the Academy;

KOLOSOK V. M. - Doctor of Economics, Professor;

ILCHENKO N. B. - Doctor of Economics, Ass. Professor;

SOLOMON D. I. - Doctor of Economics, Professor (Moldova);

ALKEMA V. H. - Doctor of Economics, Professor;

Henryk DŹWIGOŁ - PhD (Economics), Professor (Poland);

SUMETS O. M. - Doctor of Economics, Ass. Professor;

STRELCOVÁ Stanislava - PhD (Economics), Ass. Professor, (Slovakia);

RISTVEJ Jozef (Mr.) PhD (Economics), Professor, (Slovakia);

ZAMIAR Zenon - Doctor of Economics, Professor, (Poland);

SMERICHEVSKA S. V. - Doctor of Economics, Professor;

GRITSENKO S. I. - Doctor of Economics, Professor;

KARPENKO O. O. - Doctor of Economics, Professor;

PATKOVSKYI S. A. - Business practitioner.

The electronic scientific and practical journal is registered in international scientometric data bases, repositories and search engines. The main characteristic of the edition is the index of scientometric data bases, which reflects the importance and effectiveness of scientific publications using indicators such as quotation index, h-index and factor impact (the number of quotations within two years after publishing).

In 2020, the International Center for Periodicals (ISSN International Center, Paris) included the Electronic Scientific and Practical Edition "Intellectualization of Supply Chain Management" in the international register of periodicals and provided it with a numerical code of international identification: ISSN 2708-3195 (Online).

Recommended for dissemination on the Internet by the Academic Council of the Department of Logistics NAU (No. 7 of February 26, 2020). Released 6 times a year. Editions references are required. The view of the editorial board does not always coincide with that of the authors.

t.me/smart_scm facebook.com/Smart.SCM.org twitter.com/ScmSmart

DOI: https://doi.org/10.46783/smart-scm/2020-4 e-mail: support@smart-scm.org тел.: (063) 593-30-41

https://smart-scm.org 


\section{Contents}

INTRODUCTION

BUGAYKO D. O. PhD in Economics, Associate Professor, Acting Director International Cooperation and Education Institute, Instructor of ICAO Institute of National Aviation University (Ukraine), SHEVCHENKO O.R. PhD in Economics, Director of International Cooperation and Education Institute, National Aviation University (Ukraine)

INDICATORS OF AVIATION TRANSPORT SUSTAINABLE DEVELOPMENT SAFETY

$6-18$

KOSTIUCHENKO L. V. PhD in Economics, Associate Professor, Associate Professor of Department of National Aviation University (Ukraine)

THE MULTISOURCING MODEL OF SAFE SUPPLY CHAIN MANAGEMENT

$19-26$

HRYHORAK M.Yu. Doctor of Economics, Associate Professor, Head of Logistics Department National Aviation University (Ukraine), TRUSHKINA N.V. PhD (Economics), Associate Professor, Senior Research Fellow, Regulatory Policy and Entrepreneurship Development Institute of Industrial Economics of the National Academy of Sciences of Ukraine (Ukraine) DEVELOPMENT OF THE LOGISTICS SYSTEM OF THE ECONOMIC REGION "POLISSYA" IN THE CONTEXT OF THE GREEN ECONOMY: ECOLOGICAL PROBLEMS AND PERSPECTIVES

KARPUN O.V. PhD in Economics, Associate Professor, Associate Professor of Logistics Department National Aviation University (Ukraine) CONCEPTUAL MODEL OF FLORICULTURE SUPPLY CHAIN MANAGEMENT

GRITSENKO S.I., Doctor of Economics, Professor, Professor of Logistics Department National Aviation University (Ukraine), VINICHENKO I.A. Project Manager, Dudka Agency (Ukraine) (Ukraine)

PROSPECTS AND OPPORTUNITIES FOR USING FOREIGN EXPERIENCE FOR THE DEVELOPMENT OF INTELLECTUAL TRANSPORTATION SYSTEMS IN UKRAINE 
JEL Classification: C02, D24, F 52, G32, P41.

Received: 14 December 2020

Kostiuchenko L. V. PhD in Economics, Associate Professor, Associate Professor of Department of National Aviation University (Ukraine)

\author{
ORCID - 0000-0002-7635-5153 \\ Researcher ID - S-7795-2018 \\ Scopus author id: -
}

\title{
THE MULTISOURCING MODEL OF SAFE SUPPLY CHAIN MANAGEMENT
}

Lesia Kostiuchenko "The multisourcing model of safe supply chain management». The logistics outsourcing concept is to address the feasibility of using its own capabilities and sources of supply to perform certain logistics functions that the company can entrust to an external partner. However, in the current context of rapid change, it is important to make a quick and efficient decision on sources of supply: regardless of the sourcing model of the company. That is, what is the usual supply strategy for the company. Security (reliability and stability) of supplies is at the first place. Therefore, a quick decision on the optimal source of supply is the optimal solution. More precisely is the optimal combination of the use of internal resources of the company and the resources of external suppliers.

Multisourcing is a type of outsourcing used by many companies in conditions of frequent changes. Unlike traditional outsourcing, the multisourcing model involves the use of several different vendors for the same product at different times. The decision depends on the level of security. For example, with multiple sources, a company can choose the best supplier for a particular task. By outsourcing certain operations, a company can perform critical tasks on its own. These actions can achieve optimization of operating costs. However, when deciding on multisourcing, it is important to assess the risks.

It is important to estimate the cost of supply according to different options. You should compare the results of calculations and compare with the risks. These actions can ensure security of supply. So, the proposed economic and mathematical model is able to help to make the right decision of the rational choice of supply channel from several alternatives and, as a consequence, to achieve the following main goals: improving the quality of supply management; reduction of the logistics cycle; reduction of supply costs; increase the reliability of supply

Keywords: supply model, supply chain management, outsourcing, multisourcing, security of supply, costs of secure supply management.

Леся Костюченко “Мультисорсингова модель безпечного управління ланцюгами постачання". Кончепчія логістичного аутсорсингу полягає у вирішенні питання дочільності використання власних можливостей та ресурсів для виконання окремих логістичних функцій, які підприємство може довірити зовнішньому партнерові. Однак за нинішніх умов швидких змін важливим є прийняття швидкого та ефективного рішення щодо джерел постачання: незалежно від того, за якої сорсингової моделі прачює компанія. Тобто, яка стратегія постачання є звичною. На вершину цілей ставиться безпека (надійність та стабільність) поставок. Тому оптимальним $\epsilon$ 
оперативність прийняття рішення щодо оптимального джерела постачання. Точніше оптимальне поєднання використання внутрішніх ресурсів компанії та ресурсів зовнішніх постачальників.

Мультисорсинг - че вид аутсорсингу, який використовує багато компаній в умовах частих змін. На відміну від традиційного аутсорсингу, модель мультисорсингу передбачає використання декількох різних постачальників одного і того ж продукту в різний час. Рішення залежить від рівня безпеки. Запропонована економіко-математична модель спроможна допомогти у прийнятті правильного рішення щодо рачіонального вибору каналу постачання з декількох альтернативних $i$, як наслідок, досягти таких основних цілей: підвищити якість управління постачаннями; скоротити логістичний чикл; зменшити витрати на постачання; підвищити надійність постачань.

Ключові слова: модель постачання, управління ланцюгом постачання, аутсорсинг, мультисорсинг, безпека постачання, витрати на безпечне управління постачанням.

Леся Костюченко «Мультисорсинговая модель безопасного управления цепями поставок». Концепция логистического аутсорсинга заключается в поиске решения вопроса о челесообразности использования собственных возможностей и ресурсов для выполнения отдельных логистических функций, которые организачия может доверить внешнему партнеру. Однако при современных условиях частых и резких изменений важным является принятие быстрого эффективного решения об источниках снабжения: независимо от того, при какой сорсинговой модели организация работает. Т.е., какая стратегия снабжения избрана. На вершину челеполагания ставится безопасность (надежность и стабильность) поставок. Поэтому оптимальным является оперативность принятия решения касательно оптимального источника поставок. Точнее оптимальное объединение использования внутренних ресурсов организачии, а также ресурсов внешних поставщиков.

Мультисорсинг является видом аутсорсинга, который используется многими организациями в условиях частых изменений. В отличии от традиционного аутсорсинга, модель мультисорсинга предусматривает использование нескольких разных поставщиков (источников) одного и того же продукта в разное время. Решение зависит от уровня безопасности. Предложенная экономикоматематическая модель может поспособствовать принятию правильного решения о рачиональном выборе канала снабжения с нескольких альтернативных и впоследствии достичь следующих основных целей: повысить качество управления поставками; сократить логистический цикл; уменьшить затраты на снабжение; повысить надежность поставок.

Ключевые слова: модель снабжения, управление цепями поставок, аутсорсинг, мультисорсинг, безопасность поставок, затраты на безопасное управление поставками.

Introduction. Multisourcing is an effective combination of different sources of supply. It allows you to economically and quickly achieve delivery of goods from around the world. The choice of multisourcing is determined by its costeffectiveness, time savings and risk reduction. This type of transportation takes into account the specifics of the conditions of the transported goods, which increases the level of reliability of supply. Thus, it is possible to find the optimal source and delivery route.

Analysis of recent researches and publications. is to determine and substantiate the main indicators of economic and technological development, social and environmental components of air transport and assess their level. Indicators are given in groups in the above areas. Indicators are divided into stimulants (indicators that contribute to the sustainable development of air transport and the national economy) and disincentives (indicators that hinder the sustainable development of air transport and the national economy). The solution of this problem will make it possible to conduct a comprehensive assessment of the current state of air transport in Ukraine on the basis of a systematic approach. 
Table 1. Classification of supply (sourcing) models

\begin{tabular}{|l|l|}
\hline \multicolumn{1}{|c|}{ Sign of classification } & \multicolumn{1}{c|}{ Name of sourcing models } \\
\hline By number of suppliers & $\begin{array}{l}\text { Single Sourcing } \\
\text { Modular Sourcing }\end{array}$ \\
\hline On a regional-territorial basis & $\begin{array}{l}\text { Global Sourcing } \\
\text { Regional Sourcing } \\
\text { National Sourcing } \\
\text { Domestic Sourcing }\end{array}$ \\
\hline $\begin{array}{l}\text { In the presence of intermediaries in } \\
\text { the logistics channel "supplier- } \\
\text { consumer" }\end{array}$ & $\begin{array}{l}\text { Straight } \\
\text { Indirect (different levels) }\end{array}$ \\
\hline By source of supply & Insourcing \\
\hline $\begin{array}{l}\text { By the complexity of the delivery } \\
\text { option }\end{array}$ & Outsourcing \\
\hline On the scale (depth) of the \\
combination of resources & Multilevel \\
& Best-of-breed consortium \\
& Prime contractor \\
& Joint venture (JV); \\
\hline Using IT technologies & Full outsourcing \\
\hline
\end{tabular}

Source: $[2 ; 3]$

A multiple sourcing definition is outsourcing several of the company's most important operations to several different vendors instead of using a single source [5]. According to the author of [6], "the multisourcing approach contrasts with fully in-house IT provisioning and sole-source outsourcing models. Multisourcing (multisourcing) is an approach to outsourcing in which IT operations and technology infrastructure are contracted to a number of vendors, usually in combination with some internally provided elements of information technology" [6].

Multiple sourcing, which more commonly is referred to as multi-sourcing, is a type of outsourcing used by many companies. Unlike traditional outsourcing, where a single vendor handles IT responsibilities and other company operations, multi-sourcing makes use of several different vendors. Usually, the company will handle some IT tasks in-house and then outsource the rest [5].

Margaret Rouse in [6] writes that the purpose of the multisourcing was to maximize the effectiveness of an enterprise's IT by ensuring that various elements were sourced to the best possible providers, while allowing the enterprise to maintain its focus on core competencies. She highlights the following benefits of multisourcing supply:

1) Multisourcing can aid enterprise risk management programs by diversifying risk in vendor operations;

2) It can as well:

a) promote competition among various providers,

b) cut costs related to repetitive service contracts

c) improve quality, collaboration and innovation among a group of IT providers.

"Often, a company's IT vendor management office will oversee its multisourcing arrangements with input and guidance from its legal team, IT staff and other executive leadership. A good starting point is to select service-delivery providers with similar corporate cultures. In addition, organizations pursuing a multisourcing arrangement should craft strong internal 
corporate governance strategies with regard to IT vendor relationships and share the details with all of their service providers to promote better cooperation and more seamless delivery of services across organizational lines." [6].

The authors of [5] give the following advice on choosing and implementing a multisorving strategy:

- "when choosing the multi-sourcing strategy, you should make sure that someone in your IT office is monitoring arrangements with vendors (there will be an entire office dedicated to this task);

- when dealing with vendors, input from your company's IT professionals, as well as your legal team, can be helpful;

- one of the best ways to choose IT vendors is to look for companies with a corporate culture similar to your own;

- before developing arrangements with IT vendors, you need to develop a strong internal strategy for monitoring and maintaining relationships with vendors;

- you should share details of this strategy with all of your service providers to make sure that everyone is on the same page" [5].

"The cost of retaining multiple supply locations must be seen more as a cost of doing business, rather than an inefficiency.... Brexit, the U.S.-China trade war, a general geopolitical trend toward nationalization, the COVID-19 pandemic have changed the priorities of many supply chain leaders. They now need to balance cost and operational efficiency with greater resilience." [7].

On the other hand, the author emphasizes another important aspect - safe (reliability and stability). "Only $21 \%$ of respondents stated that they have a highly resilient network today, meaning good visibility and the agility to shift sourcing, manufacturing and distribution activities around fairly rapidly. It suggests that increasing resilience will be a priority for many as they emerge from the current crisis. More than half expect to be highly resilient within two to three years inefficiency." [7].
"In 2011, major natural disasters in Japan and Thailand disrupted supply chains across the world and exposed companies' reliance on single sources of supply. In the automotive industry, nearly finished cars could not be shipped to customers because of missing, and often inexpensive, components. Multisourcing is an obvious way to mitigate this risk." [7]. So Sarah Hippold offers "to craft a multisourcing strategy, supply chain leaders must know their supplier networks in detail and be able to categorize suppliers not just by spend, but also by revenue impact if a disruptive event occurs". Author proves that "diversification can be achieved by awarding business to additional suppliers or working with an existing single- or sole-source supplier that is able to produce out of several locations" [7].

However beyond multisourcing, some companies want to reduce geographic dependence in their global networks and shorten cycle times for finished products. It can be nearshoring. Regional or local supply chains can be more expensive, because they add more players and complexity to the ecosystem, but they allow for more control over inventory and move the product closer to the end consumer [7].

Multi-sourcing is significantly different from handling IT operations completely within the company or outsourcing these duties to a single vendor. Making IT operations more effective is the idea behind multi-sourcing. With multi-sourcing, a company can choose the best vendor for a given IT task. By outsourcing certain IT operations, the company can handle the most important responsibilities internally. It can provide several other benefits to companies that choose this strategy and there are several factors that can determine the benefits and drawbacks a company can experience from multiple sourcing. [5]

Based on the results of the research we can present such advantages of multimodal transportation as show in the Table 2 
Table 2. Factors and reasons for the benefits and shortcomings of multisourcing

\begin{tabular}{|l|l|}
\hline Benefits of multisourcing & Shortcomings of multisourcing \\
\hline $\begin{array}{l}\text { Sparking competition between } \\
\text { vendors }\end{array}$ & The complexity of the arrangement \\
\hline $\begin{array}{l}\text { Lowering the costs and improving the } \\
\text { quality of service contracts }\end{array}$ & The availability of unique materials. \\
\hline $\begin{array}{l}\text { Allowing IT providers to innovate and } \\
\text { collaborate }\end{array}$ & $\begin{array}{l}\text { The using of necessary Bill of Materials of a } \\
\text { product }\end{array}$ \\
\hline $\begin{array}{l}\text { It can help to protect a company from } \\
\text { the risk of demand variability }\end{array}$ & $\begin{array}{l}\text { Weakening the concentration of attention on } \\
\text { a particular supplier (supply chain can be } \\
\text { easily disrupted) }\end{array}$ \\
\hline
\end{tabular}

Source: revised by the author on the basis of $[2 ; 4 ; 5]$

However, keep in mind that the biggest drawback of multi-sourcing is that your supply chain can be easily disrupted because you'll be working with multiple vendors. Because "every supplier that you use will have a much lower volume of business transactions than with single-source outsourcing, they will not be as motivated to maintain efficiency and to make sure there are no bottlenecks in the supply chain. Obviously, this increases the risk for the company that purchases the supplier's services." [5].

Factors and reasons for the benefits and shortcomings of multisourcing which are given in the table 2 we can be explained as follows [5]:

1) With multi-sourcing, your company will need to be much more proactive about managing your relationships with vendors so that you can avoid frequent disruptions of your supply chain.

2) The biggest strength of multiple sourcing is that you will not be overly reliant on a single supplier. If one of your vendors is frequently experiencing supply chain disruptions that are affecting your business, you can shift that vendor's responsibilities to another supplier. Choosing a multi-sourcing strategy means you'll be able to lower the risks of supply disruption and will make sure that you're not dependent on one vendor.

3) Multi-sourcing can also help to protect your company from the risk of demand variability. When you have relationships with multiple vendors and demand sharply increases, you can spread this demand among all of your vendors, ensuring you can meet customer demand without overwhelming your suppliers. Many companies use multisourcing to help lower their prices. By using multiple vendors, you may be able to spark a bidding war for your contract, which can result in you paying a much lower price than you would when working with a single vendor.

4) In most cases, a company can replace a supplier without affecting any of its other contracts. Depending on the service provided by the supplier, however, a company may need to change their arrangements with the remaining suppliers when ending a supplier relationship. When you need to end a supplier relationship and update your relationship with your other suppliers, you should alert your customers so that they can prepare for any changes in their IT support. If the management of company wants to keep your costs as low as possible, you should make sure that you aren't duplicating tasks across your vendors and within your company. On the other hand, task duplication is a common way to lose money.

The importance of determining and evaluating the criteria for choosing a rational supply channel is described in detail and proved in the monograph [1, p.451 - 453].

The purpose and objectives of the study. Analysis of the publications of the 
above authors shows that views on the essence and content of multi-resources for practical logisticians and academic experts do not differ. However, the studied publications do not have ways to assess the level of risks and total costs of supply chain management process taking into account the level of security.

That is why the purpose of this study is to find a scientifically sound mathematical model for calculating the total cost of supply management, taking into account the level of security.

Basic material and results. Based on the study and in accordance with its purpose, we propose an economic and mathematical model for determining the total cost of supply chain management for a certain period of time, taking into account the security of multisourcing supply:

$$
\sum C_{S C M}=\sum_{i \in I} \sum_{j \in J} \sum_{k \in K} \sum_{t \in T}\left(C_{C_{i j k t}} \cdot N_{S C i j k t} \cdot y_{S f_{i j k t}}+C_{C A i j k t} \cdot N_{C l i j k t}\right) \Rightarrow \min ,
$$

where: $\sum C_{S C M_{t}}$ - total costs of supply chain management for the $t$-th period of time;

$C_{c i j k t}-\quad$ costs for ensuring the supply of the $i$-th batch taking into account the $j$-th need $k$-th supply channel for the $t$-th period of time;

$N_{s c i j k t}-\quad$ the number of deliveries of the $i$-th batch taking into account the $j$-th need $k$ th supply channel for the $t$-th period of time;

$y_{s f i j k t}-\quad$ variable that reflects the level of safe (reliability, stability) in the supply of the $i$-th batch, taking into account the $j$-th need $k$-th supply channel for the $t$-th period of time;

$C_{\text {CAijkt }}$ - costs of claims activity related to the supply of the $i$-th batch, taking into account the $j$-th need $k$-th supply channel for the $t$-th period of time;

$N_{\text {clijkt }}$ - the number of claims for the supply of the $i$-th batch, taking into account the $j$-th need $k$-th supply channel for the $t$-th period of time.

This model reaches its maximum value subject to such restrictions:

- by reliability (stability) of the k-th supply channel for the $t$-th period at purchase $i$ - th batch, taking into account the $j$-th need (with $t=T_{\mathrm{L}}$ (lower limit); $T=T_{\mathrm{H}}$ (upper limit)):

$$
\sum_{k \in K} \sum_{t \in T} N_{S C k t} \leq \sum_{k \in K} \sum_{t \in T} N_{C l k t} \cdot y_{k t}
$$

where: $N_{S C k t}$ - possible number of deliveries

by the $k$-th supply channel for the $t$-th period;

- on the flexibility of procurement policy (procurement frequency planning):

$$
\begin{gathered}
12 \leq \sum_{j \in J} \sum_{k \in K} N_{S C k t} \leq 48 \text { (the number per } \\
\text { year); }
\end{gathered}
$$

- by the amount of supply chain management funding for the $t$-th period of time:

$$
\sum_{k \in K} y_{S f} \cdot C_{S C M k t} \leq \sum_{t \in T} C_{S C M_{t}}
$$

where: $\sum C_{S C M}{ }_{k t}-$ total costs of supply chain management for the $k$-th supply channel for the $t$-th period of time;

- on the reliability (stability) of the $k$-th supply channel for the $t$-th period according to the previous one:

$$
N_{S C M k t}=N_{S C M k t-1} \cdot y_{k t-1} \text {; }
$$

- as well as under such next conditions: $i \in I ; j \in J ; k \in K ; t \in T$. 
Variable that reflects the increase in reliability (stability) of the $k$-th supply channel for the $t$-th period of time $\left(y_{S f} k t\right)$ determines by the formula:

$$
y_{S f_{k t}}=\frac{N_{S C M k t} K_{\mathrm{unev}}}{t},
$$

where: $K_{\text {unev }}-\quad$ coefficient of uneven supply, which is calculated by the formula:

$$
K_{\text {нер }}=k_{\text {доб }} \cdot k_{\text {год, }}
$$

where: $k_{\text {year/season }}$ - macro indicator relative to $t$ - year/season coefficient of nonuniformity,

$$
k_{\text {year/ season }} \rightarrow(1,3-1,9) \text {; }
$$

$k_{\text {day }}-$ micro indicator relative to $t-$ day coefficient of non-uniformity,

$$
k_{\text {day }} \rightarrow(2,0-4,0) \text {. }
$$

The proposed economic and mathematical model will allow to make the right decision of the rational choice of supply channel from several alternatives and, as a consequence, to achieve the following main goals:
1) improving the quality of supply management;

2) reduction of the logistics cycle;

3) reduction of supply costs;

4) increase the reliability of supply $\left(N_{S C M} \rightarrow o p t, y_{\text {Saf }} \rightarrow \max \right)$.

Conclusions. Scientific analysis of key steps and elements of creating a mathematical model for calculating the total cost of supply management, taking into account the level of security, gives the following conclusions:

1. The proposed economic and mathematical model reaches its maximum value subject to certain limitations that must be taken into account.

2. This model will allow making the right decision of the rational choice of supply channel from several alternatives.

3. The proposed economic and mathematical model will allow to make the right decision of the rational choice of supply channel from several alternatives and, as a consequence, to achieve the following main goals: improving the quality of supply management; reduction of the logistics cycle; reduction of supply costs; increase the reliability of supply.

\section{References}

1. Grigorak, M. Yu. (2017). Intelektualizatsiya rinku logistichnih poslug: kontseptsiya, metodologiya, kompetentnist: monografiy [Intellectualization of the logistics services market: concept, methodology, competence], Sik Grup Ukrayina, Kyiv, Ukraine.

2. Kostiuchenko, L. (2020). "The methodology of enterprise logistic activity strategic analyse", Efektyvna ekonomika, vol. 5, available at: http://www.economy.nayka.com.ua/?op=1\&z=7872 (Accessed 20 Jul 2020).

3. Kostiuchenko, L. (2009). Sorsinhova model upravlinnia systemoiu materialno-tekhnichnoho zabezpechennia zaliznychnoi haluzi [Sourcing model of management of the logistics system of the railway industry], Problemy pidvyshchennia efektyvnosti infrastruktury. vol. 21, p. 170-179. NAU, Kyiv, Ukraine

4. Kulyk, V.A., Grigorak, M.Iu. and Kostiuchenko (2013). Lohistychnyi menedzhment [Logistics management], Logos, Kyiv, Ukraine.

5. Multiple Sourcing Definition (2020). Strengths and Weaknesses of Multiple Sourcing, available at: https://www.upcounsel.com/multiple-sourcing-definition 
6. Margaret Rouse (2011). Multisourcing (multi-sourcing) // Techtarget [Online]: https://searchcio.techtarget.com/definition/Multisourcing July 2011

7. Sarah Hippold (2020). In the wake of COVID-19 and other disruptions, supply chain leaders have to balance resilience and efficiency to secure their networks // Smarter With Gartner / June 23, 2020: available at: https:/www.gartner.com/smarterwithgartner/6-strategies-for-a-moreresilient-supply-chain/ 